\title{
The effects of social media marketing, store environment, sales promotion and perceived value on consumer purchase decisions in small market
}

\author{
Haudi $^{a^{*}}$, Ruby Santamoko ${ }^{\mathrm{a}}$, Arief Rachman ${ }^{\mathrm{b}}$, Yunan Surono ${ }^{\mathrm{c}}$, Riko Mappedeceng ${ }^{\mathrm{c}}$, Musnaini $^{\mathrm{d}}$ \\ and Hadion Wijoyo
}

${ }^{a}$ STAB Dharma Widya, Tangerang, Banten, Indonesia

${ }^{b}$ FEB Universitas Airlangga, Indonesia

${ }^{c}$ Universitas Batanghari, Jambi, Indonesia

${ }^{d} \mathrm{FEB}$ Universitas Jambi, Indonesia

eSTMIK Dharmapala Riau, Indonesia

\section{H R O N I C L E A B S T R A T}

Article history:

Received: June 20, 2021

Received in revised format: July

28, 2021

Accepted: October 4, 2021

Available online: October 4, 2021

Keywords:

Social Media Marketing

Store Environment

Sales Promotion

Perceived Value

Purchase Decision

Small market

\begin{abstract}
The purpose of this research is to analyze the influence of social media marketing on small market purchase decisions and to analyze the influence of the store environment on small market purchase decisions. The study also analyzes the influence of sales promotion on small market purchase decisions as well as the effect of perceived value on small market purchase decisions. The study uses a quantitative method and data collection is performed by distributing questionnaires to 170 respondents who have bought goods in the small market. The research method in this study uses structural equation modeling (SEM) analysis using SmartPLS software. The results of this study reveal that all independent variables have some positive effects on consumer buying decisions. More specifically, the variables of small market environmental conditions, sales promotions, and profit values have significant influences on consumer buying decisions, while social media marketing variables has no significant effect on consumers' buying decisions.
\end{abstract}

\section{Introduction}

In this era of the industrial and digital revolution, one of the businesses that is experiencing rapid development from year to year is the small market. According to Huazam et al. (2016), the high level of public consumption triggers entrepreneurs to develop their business in the retail sector. The variety of existing retailers causes the emergence of containers that combine several retail businesses that offer a number of similar or different goods in small volumes called small markets. In the research of Handi et al. (2018), regarding the influence of social media on buying decisions, it is found that social media marketing is an important factor influencing consumer buying decisions because of the high number of social media users today. Another study (Dhar et al., 2014) also reported that the importance of building an attractive store environment is a very important factor and influences consumers' buying decisions because creating a pleasant and unique store atmosphere is a very important factor. According to Hanaysha (2016), adding certain values (perceived value) is important in building customer loyalty and satisfaction. In another study, Dhar et al. (2014) also stated that sales promotion regarding selling price is one of the most frequently used strategies by marketing managers to increase sales. Therefore, this study was conducted to determine the effect of social media marketing, store environment, sales promotion, and perceived value on the decision to buy small markets

* Corresponding author.

E-mail address: aguspurwanto.prof@gmail.com (Haudi)

(C) 2022 by the authors; licensee Growing Science, Canada. doi: $10.5267 /$ j.ijdns.2021.10.003 
(Aji et al., 2020; Amril et al. ,2020). According to Ramanathan et al. (2017) business activities sell goods or services to individual consumers for their own, family, or household needs. According to Goh et al. (2013) retailing is a series of business activities to add value to goods and services sold to consumers for personal or household consumption. According to Prahiawan et al. (2021) retailing is a business venture that seeks to market goods and services to end consumers who use them for personal and household purposes. Purchase decision according to Purba et al. (2021), Ramanathanet al. (2017) are consumer behavior in treating consumer decision making as a solution to the problems they face. According to Goh et al. (2013) purchase decision is a basic psychological process that plays an important role in understanding how consumers make purchasing decisions. According to Prahiawan et al. (2021), the consumer decision process does not end with the purchase but continues until the purchase becomes an experience for consumers in using the purchased product. According to Purba et al. (2021) and Ramanathanet al. (2017), social media is a medium used by consumers to share text, images, sound, and videos that were previously unavailable to ordinary people. According to Javid et al. (2019) and Prahiawan et al. (2021) social media are texts, images, videos, and online links that are shared between people and individuals. According to Purba et al. (2021) and Ramanathan et al. (2017), social media is an internet platform that allows individuals to share quickly and communicate continuously with their communities.

According to Salimi et al. (2019), the store environment is an important element in retailing given that $70 \%$ of purchases turn out to be unplanned purchases. According to Rombe et al. (2021), the store environment can also affect in-store purchases, supported by the theory that a planned store atmosphere can attract consumers to buy. Sales promotion according to Uzir et al. (2021) is defined as a collection of incentive tools, mostly short term, designed to stimulate faster and greater purchase of certain products or services by consumers or traders. According to Pourkhani et al. (2019), sales promotion is a retailer's promotion program in order to boost sales or to increase sales or in order to maintain customer interest to keep shopping with him. According to Salimi et al. (2019) and Pourkhani et al. (2019), Perceived Value Customer perceived value is a trade-off between perceived benefits and perceived sacrifices. According to Rombe et al. (2021) and Adinugraha et al. (2021) the perceived benefits are a combination of a number of elements, namely: physical attributes, service attributes and technical support obtained in using the product. While the perceived sacrifice consists of all purchase costs incurred at the time of purchase; for example the purchase price, acquisition costs, transportation, installation, handling, repair and maintenance costs, and the risk of failure or poor performance. According to Van et al. (2014) and Wijayaa et al. (2021), perceived value is a consumer's overall assessment of the benefits of a product based on what they receive and what they provide. The objectives of this research are: 1 . To determine the effect of social media marketing on small market purchase decisions, 2 . To determine the influence of the store environment on small market purchase decisions, 3 . To determine the effect of sales promotion on small market purchase decisions and 4 . To determine the effect of perceived value on small market purchase decisions.

\section{Method}

The subject of this research is Small Market. The selection of the subject of this research with the consideration of the Small Market. This is a Department Store that has a steady growth from year to year. Sampling in this study used a purposive sampling technique, which is a technique to determine the research sample with certain considerations aimed at making the data obtained more representative (Sugiyono, 2012). So that the selected sample is consumers who have bought goods at the Small Market. According to Purwanto et al. (2010) the number of samples used in a study was 170 people. Data analysis used structural equation modeling (SEM) analysis using SmartPLS software. Data were obtained through the distribution of online questionnaires. The SmartPLS test criteria are the value of the loading factor must be greater than 0.70, Composite Reliability Composite Reliability measures internal consistency and the value must be greater than 0.60 , the value of Average Variance Extracted (AVE) must be greater than 0.50, Discriminant Validity The square root value of AVE must be greater than the correlation value between latent variables (Purwanto et al., 2021). Based on theoretical studies and previous studies, the research model is structured as follows:

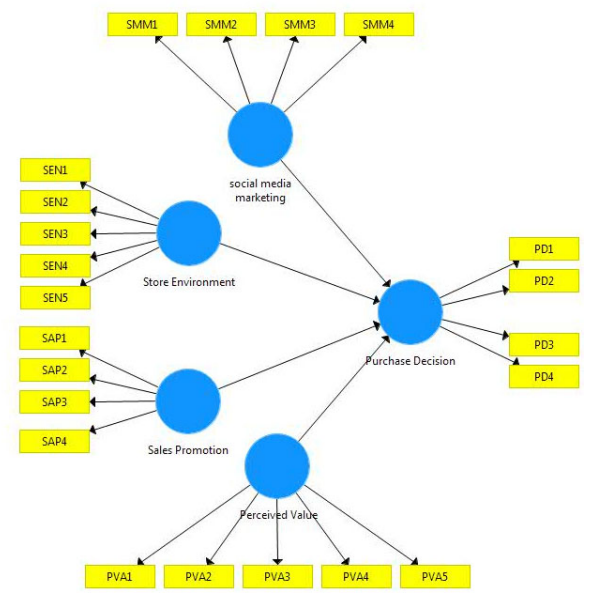

Fig. 1. Research Model 
Based on the explanation above, the hypotheses proposed in this study are as follows:

H1: Social media marketing has a significant effect on purchase decisions.

H2: Store environment has a significant effect on purchase decisions.

$\mathbf{H}_{3}$ : Sales promotion has a significant effect on purchase decisions.

H4: Perceived value has a significant effect on purchase decisions.

\section{Result and Discussion}

The results of the reliability test use Partial Least Square (PLS). A variable is reliable if the value of its composite reliability is greater than 0.7. Measuring the reliability does not use Cronbach's alpha because the use of composite reliability in testing construct reliability can provide a better value when compared to Cronbach's alpha (Purwanto et al., 2021). Table 1 shows that all existing variables have met the requirements of composite reliability since the results obtained have met the recommended number, which is greater than 0.7 which is considered that all statements or items of all variables studied are reliable. The composite reliability value of each indicator can be seen in table 1 below

Table 1

Reliability

\begin{tabular}{lll}
\hline Variables & Cronbach's Alpha & Composite Reliability \\
\hline Social media marketing & 0.882 & 0.919 \\
Store environment & 0.944 & 0.958 \\
Sales promotion & 0.727 & 0.829 \\
Perceived value & 0.808 & 0.861 \\
Purchase decision & 0.838 & 0.891 \\
\hline
\end{tabular}

In Table 1, it can be seen the results of the reliability test analysis using the SmartPLS tool which states that all composite reliability values are greater than 0.7 , which means that all variables are reliable and have met the test criteria.

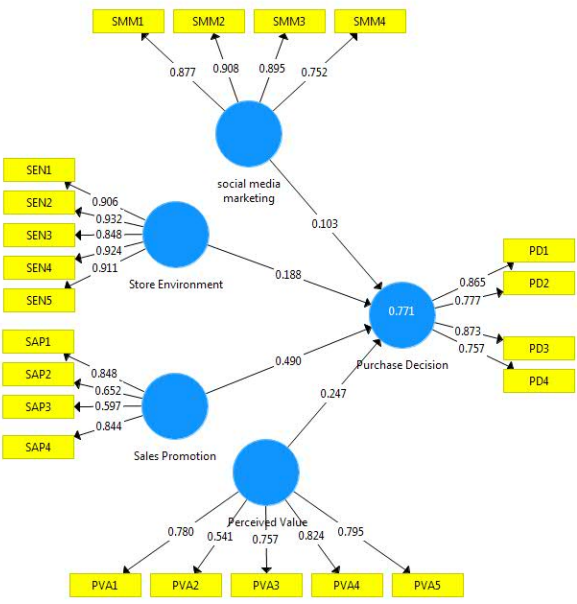

Fig. 2. The results of convergent validity

Discriminant validity is carried out in two stages, namely by looking at the value of the cross-loading factor and comparing the AVE roots with the correlation between constructs/latent variables. Cross loading factor is used to find out whether the latent variable has an adequate discriminant by comparing the correlation of the indicator with the latent variable must be greater than the correlation between the indicator and other latent variables. If the correlation of the indicator with its latent variable has a higher value than the correlation of the indicator to other latent variables, it is said that the latent variable has high discriminant validity and the recommended AVE value is 0.5 (Purwanto et al., 2020). According to Table 2, the AVE value for all variables is $>0.50$. So, it can be said that the measurement model has been valid with discriminant validity.

Table 2

The results of AVE

\begin{tabular}{lc}
\hline Variables & AVE \\
\hline Social media marketing & 0.740 \\
Store environment & 0.819 \\
Sales promotion & 0.553 \\
Perceived value & 0.557 \\
Purchase decision & 0.672 \\
\hline
\end{tabular}


The value of the coefficient of determination ( $R^{2}$ or $R$-square) is close to the value of 1 . The value of $R^{2}$ for the dependent construct indicates the magnitude of the influence/accuracy of the independent construct in influencing the dependent construct. The value of $\mathrm{R}^{2}$ explains how much the hypothesized exogenous variable in the equation can explain the endogenous variable. This $R^{2}$ value in PLS is also called $Q$-square predictive relevance. The magnitude of $R^{2}$ is $0 \leq R^{2} \leq 1$. The greater the $\mathrm{R}^{2}$ value, the better the resulting model (Purwanto, 2019). In this study, the adjusted R-square value is used, because it has more than two independent variables.

Table 3

R-square adjusted

\begin{tabular}{ll}
\hline Variables & R-square adjusted \\
\hline Purchase decision & 0.771 \\
\hline
\end{tabular}

In Table 3 it can be explained that the adjusted $\mathrm{R}^{2}$ value of the independent variable Social media marketing Store environment, Sales promotion, Perceived value of the dependent variable purchase decision is 0.771 . This value is categorized as weak. Independent variables of Social media marketing Store environment, Sales promotion, Perceived value contributed to the dependent variable purchase by $77.1 \%$ while the remaining $22.9 \%$ was influenced by other variables not discussed in this study.

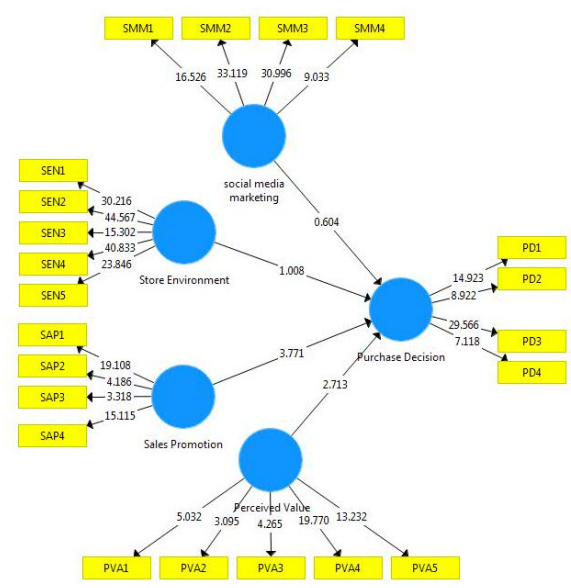

Fig. 3. Hypotheses Testing

\section{Hypothesis test}

The hypothesis testing that will be proposed in this study uses the Partial Least Square (PLS) analysis technique which is operated through Smart PLS 3 software. All independent variables affect the dependent variable (Purwanto et al., 2020). The hypothesis is said to be significant if it has a probability value ( $p$-value) $<5 \%$.

Table 4

Hypotheses Testing for Direct Effect

\begin{tabular}{lcc}
\hline Hypotheses & Pesult & Value \\
\hline Social media marketing -Purchase decision & 0.001 & Significant \\
Store environment-Purchase decision & 0.001 & Significant \\
Sales promotion-Purchase decision & 0.005 & Significant \\
Perceived value-Purchase decision & 0.003 & Significant \\
\hline
\end{tabular}

The relationship between social media marketing and purchase decision

Based on the results of data analysis using SmartPLS, we have obtained p-value of $0.001<0.050$ so it can be concluded that Social media marketing has a significant effect on company competitiveness, an increase in Social media marketing has a significant effect on increasing Purchase decision and decreasing Social media marketing variables will have a significant effect on decreasing Purchase. These results are in line with the research conducted by Aji et al. (2020), Amril et al. (2020), Dhar et al. (2014), Handi et al. (2018) and Huazam (2016) and confirm that social media marketing has a positive and significant effect on purchase decisions.

\section{The relationship between social media store environment and purchase decision}

Based on the results of data analysis using SmartPLS, we have obtained a p-value of $0.001<0.050$ and it can be concluded that the store environment has a significant effect on purchase decisions, an increase in the store environment variable will 
have a significant effect on increasing the purchase decision variable and a decrease in the store environment variable will have a significant effect on the decrease in the purchase decision. These results are in line with the research conducted by Goh et al. (2013), Javid et al. (2019), Prahiawan et al. (2021), Purba et al. (2021) and Ramanathan et al. (2017).

\section{The relationship between sales promotion and purchase decision}

Based on the results of data analysis using SmartPLS, the p-value is $0.005<0.050$ and it can be concluded that sales promotion has a significant effect on purchase decisions and an increase in sales promotion variables will have a significant effect on increasing purchase decision variables and decreasing sales promotion variables will have a significant effect on decreasing purchase decision. These results are in line with the research conducted by Salimi et al. (2019), Pourkhani et al. (2019), Uzir et al. (2021) and Rombe et al. (2021) that sales promotion has a positive and significant effect on purchase decisions.

\section{Relationship between Perceived value and Purchase decision}

Based on the results of data analysis using SmartPLS, we have obtained p-value of $0.004<0.050$ and we can conclude that the Perceived value has a significant effect on Purchase decisions. In other words, an increase in the Perceived value will have a significant effect on increasing the Purchase decision variable and a decrease in the Perceived value will have a significant influence on the decrease in the Purchase decision. These results are in line with the research conducted by Van et al. (2014), Wijayaa et al. (2021) and Zhao and Chen (2021).

According to Adinugraha et al. (2021) in marketing communications, online and social media marketing are in great demand by various companies because the costs are more economical when compared to other marketing communication activities, the increasing number of netizens is also a great opportunity for companies, this is one of the reasons why online and social media marketing was chosen as a strategy to reach new consumers. Online and social media marketing is not only about social media, but also it is used for online marketing such as social media marketing. Purchase intention is one component of consumer cognitive behavior in how an individual has the intention to buy a certain brand. Research conducted by Adinugraha et al. (2021) uses the context of purchase intention in online media, so that the purchase intention that is created is a situation where consumers are willing and intend to carry out online transactions in the form of activities in the process of procuring information, transferring information and purchasing products. According to research conducted by Affandi et al. (2020), purchase intention is the intention of an individual to buy a certain brand that is selected after conducting several evaluations. In this study, in more detail, it discusses online purchase intention, where consumers are involved in transactions in online media. The transaction is in the form of consumers getting information transfer from online media, then being able to purchase products on the online media. Aji et al. (2020) define purchase intention as a form of decision making that studies the reasons a consumer buys a certain brand. In this study, more further explained that consumer purchasing decisions are complex processes, because they are influenced by various kinds of internal and external motivations from consumers (Amril et al., 2020). Consumers need to feel interested in a product before consumers can finally have interest to buy the product. To build this interest, consumers need to know the necessary information about a product (Dar et al., 2014). Purchase intention is conceptualized as a dimension of consumer loyalty in an offline setting. This understanding means that consumer loyalty is built since consumers start making purchases, or since there is an interest in buying from consumers in a product. Based on the concept of social media and marketing described earlier, it can be seen that marketing activities which consist of creating, communicating, and conveying consumer needs can be carried out using a communication system in internet media that runs in two directions, namely social media. The following is an expert's understanding of social media marketing. Affandi et al. (2020) state that social media marketing is a form of two-way communication with the aim of providing opportunities to reduce misunderstandings about brands and increase the value of a brand by creating a platform to share ideas and information with people online. Handi et al. (2018) stated that social media marketing is a form of internet marketing model that refers to achieving marketing goals by participating in various social media networks. Forms of participation in social media generally consist of the use of BBS, micro blogging, blogs, websites, social networking sites and others. Handi et al. (2018) explain that there are several objectives of social media marketing, including stimulating sales, increasing brand awareness, increasing brand image, creating traffic for online platforms, reducing marketing costs and creating interactive activities with consumers.

\section{Conclusion}

Based on the results of the study, the conclusion of this study is that social media marketing has an insignificant effect on the purchase decision of small market consumers. The store environment has a significant influence on the purchase decision of small market consumers. Sales promotion has a significant influence on the purchase decision of small market consumers. Perceived value has a significant influence on the purchase decision of small market consumers. Based on the results of this study, there are several suggestions that can be given by researchers, namely for practitioners. The indicator of the research variable that has the highest average value is that the small market always looks clean. This means that the small market management must maintain and always pay attention to cleanliness in every shop. The indicator of the research variable that has the lowest average value is that advertisements on social media are easy to remember. This means that the small market management does not need to focus too much on activities on social media because apart from social media having a low average value, social research variables media marketing also has no significant effect on consumer buying decisions. This study only uses four independent variables, namely social media marketing, store environment, sales promotion, and perceived 
value to measure the influence of small market consumer purchase decisions. There are still other factors that have the potential to influence the purchase decision of small market consumers that can be investigated further, such as personal factors, social factors, and psychological factors.

\section{References}

Adinugraha, H. H., Nasution, I. F. A., Faisal, F., Daulay, M., Harahap, I., Wildan, T., ... \& Purwanto, A. (2021). Halal Tourism in Indonesia: An Indonesian Council of Ulama National Sharia Board Fatwa Perspective. The Journal of Asian Finance, Economics and Business, 8(3), 665-673.

Affandi, A., Sarwani, A. S., Erlangga, H., Siagian, A. O., Purwanto, A., Effendy, A. A., \& Juhaeri, G. (2020). Optimization of MSMEs Empowerment in Facing Competition in the Global Market during the COVID-19 Pandemic Time. Systematic Reviews in Pharmacy, 11(11), 1506-1515.

Aji, P., Nadhila, V., \& Sanny, L. (2020). Effect of social media marketing on Instagram towards purchase intention: Evidence from Indonesia's ready-to-drink tea industry. International Journal of Data and Network Science, 4(2), 91-104.

Amril, D. (2020). Influence of Packaging, Price, Promotion and Perceived Value on Purchase Decision at Snack Business 88 Solok. Technium Social Sciences Journal., 8, 489.

Dhar, J., \& Jha, A. K. (2014). Analyzing social media engagement and its effect on online product purchase decision behavior. Journal of Human Behavior in the Social Environment, 24(7), 791-798.

Handi, H., Hendratono, T., Purwanto, E., \& Ihalauw, J. J. (2018). The effect of e-WOM and perceived value on the purchase decision of foods by using the go-food application as mediated by trust. Quality Innovation Prosperity, 22(2), 112-127.

Huazam, A. (2016). The Effect of Social Media Sales Promotion towards Customer Purchase Decision. Journal of Postgraduate Current Business Research, 1(1), 1-7.

Goh, K. Y., Heng, C. S., \& Lin, Z. (2013). Social media brand community and consumer behavior: Quantifying the relative impact of user-and marketer-generated content. Information Systems Research, 24(1), 88-107.

Javid, E., Nazari, M., \& Ghaeli, M. (2019). Social media and e-commerce: A scientometrics analysis. International Journal of Data and Network Science, 3(3), 269-290.

Prahiawan, W., Fahlevi, M., Juliana, J., Purba, J., \& Tarigan, S. (2021). The role of e-satisfaction, e-word of mouth and etrust on repurchase intention of online shop. International Journal of Data and Network Science, 5(4), 593-600.

Purba, J., Samuel, S., \& Budiono, S. (2021). Collaboration of digital payment usage decision in COVID-19 pandemic situation: Evidence from Indonesia. International Journal of Data and Network Science, 5(4), 557-568.

Purwanto, A., Asbari, M., Santoso, T. I., Paramarta, V., \& Sunarsi, D. (2020). Social and Management Research Quantitative Analysis for Medium Sample: Comparing of Lisrel, Tetrad, GSCA, Amos, SmartPLS, WarpPLS, and SPSS. Jurnal Ilmiah Ilmu Administrasi Publik, 10(2), 518-532.

Purwanto, A., Asbari, M., Santoso, T. I., \& Haque, M. G. (2019). Marketing Research Quantitative Analysis for Large Sample: Comparing of Lisrel, Tetrad, GSCA, Amos, SmartPLS, WarpPLS, and SPSS. Jurnal Ilmiah Ilmu Administrasi Publik, 9(2), 355-372.

Purwanto, A., Asbari, M., Santoso, T. I., Sunarsi, D., \& Ilham, D. (2021). Education Research Quantitative Analysis for Little Respondents. Jurnal Studi Guru Dan Pembelajaran, 4(2), 335-350.

Ramanathan, U., Subramanian, N., \& Parrott, G. (2017). Role of social media in retail network operations and marketing to enhance customer satisfaction. International Journal of Operations \& Production Management.

Salimi, D., Tavasoli, K., Gilani, E., Jouyandeh, M., \& Sadjadi, S. (2019). The impact of social media on marketing using bibliometrics analysis. International Journal of Data and Network Science, 3(3), 165-184.

Pourkhani, A., Abdipour, K., Baher, B., \& Moslehpour, M. (2019). The impact of social media in business growth and performance: A scientometrics analysis. International Journal of Data and Network Science, 3(3), 223-244.

Uzir, M. U. H., Hamid, A. B. A., \& Latiff, A. S. A. (2021). Does customer satisfaction exist in purchasing and usage of electronic home appliances in Bangladesh through interaction effects of social media?. International Journal of Business Excellence, 23(1), 113-137.

Rombe, E., Zahara, Z., Santi, I., \& Rahadhini, M. (2021). Exploring e-mobile banking implementation barriers on Indonesian millennial generation consumers. International Journal of Data and Network Science, 5(4), 579-586.

Wijayaa, O., Sulistiyanib, S., Pudjowatic, J., Kurniasih, N., \& Purwanto, A. (2021). The role of social media marketing, entertainment, customization, trendiness, interaction and word-of-mouth on purchase intention: An empirical study from Indonesian smartphone consumers. International Journal of Data and Network Science, 5(3), 231-238.

Zhao, S., \& Chen, L. (2021). Exploring Residents' Purchase Intention of Green Housings in China: An Extended Perspective of Perceived Value. International Journal of Environmental Research and Public Health, 18(8), 4074.

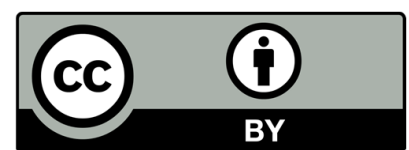

(C) 2022 by the authors; licensee Growing Science, Canada. This is an open access article distributed under the terms and conditions of the Creative Commons Attribution (CC-BY) license (http://creativecommons.org/licenses/by/4.0/). 